\title{
REPRESENTATION OF ISLAMIC CULTURE ON INDONESIAN LANGUAGE TEXTBOOKS IN MADRASAH
}

\author{
Nuryani \\ Syarif Hidayatullah State Islamic University Jakarta, J1. Ir. H. Djuanda 95, Ciputat, Indonesia \\ Corresponding e-mail: nuryani@uinjkt.ac.id
}

\begin{abstract}
The aim of this study is to describe representation of Islamic Culture on Indonesian language textbooks in madrasah for the past two years. Islamic education should be able to realize the elements of Islam in every component of teaching, one of them in the preparation and use of textbooks for each subject. The method of data presentation used in this study is descriptive qualitative, which will describe the data and analysis result in depth. With this research we will get a clear picture about the representation of Islamic culture presented. The expected implication of this research is the result will be the input of various parties in the preparation of textbook. Thus, some components of teaching in Islamic schools are able to reflect Islamic values. In the end, Islamic schools are able to become the leading schools in shaping the generation of Indonesia with strong Indonesian and Islamic principles.
\end{abstract}

Kata kunci: representation of Islamic Culture, Indonesian language textbooks, madrasah

\section{RESEARCH BACKGROUND}

Tarmizi Taher mentions there are several tasks carried by Departemen Agama (and now we call Kementerian Agama) (Taher, 1998: 26-27).

The main task is carry out some of the tasks of government and development functions in the field of religion. That main task related with the folowing functions:

a. Formulate operational and technical policies of goverment;

b. Provide guidence and direction in the field of religion in accordance with the general policy of teh president;

c. Taking care of the govermnet's wealth entrusted to the Ministry of Religious Affairs; and

d. Doing the main tasks base on applicable regulation.

The Ministry of Religious Affairs has the following main task.

a. Building the religious life of Indonesian society;

b. Maintaining religious harmony; and c. Participate in efforts to improve social welfare (Taher, 1998: 27).

In an effort to participate in improving social welfare, the Ministry of Religious Affairs get the mandate to organize the education system which is under shade the Ministry of Religious Affairs and regardless of the Ministry of Education and Culture. Because, regardless from the Ministry of Education and Culture there must be a distinction (uniqueness) owned by the education system under the Ministry of Religious Affairs.

It was wide implications. Educational providers under the Ministry of Religious Affairs are required to always include the elements of Islam in component of teaching.

In addition to inserting in each component, Islamic culture should also be reflected in every behavior and atmosphere of education provider. Because the culture and Islamic values are not really located on sahadat, salat (prayer), fasting, zakat, and haji (hajj) as it is in teh Pillars of Islam (Rukun Islam), but more than that. However, the magnitude of responsibilities carried out has not been fully implemented and fulfilled by providers of Islamic education, so that implementation in the field has not been seen so that the impact of Islamic culture. Components that are clearly visible and everyday 
used by teachers and students are textbooks. Textbooks become the first reference for teachers and students to conducting learning activities. For that, in every textbooks must contain a clear Islamic culture that can be emulated either directly or indercetly by students, teachers, and those who read. Islamic culture is not only belongs Islamic Education, but must be owned by every subject, include Indonesian Language. Indonesian Language has a functions as a science advocate and has considerable amount of teaching hours. For that, in Indonesian Language textbooks should also be included Islamic culture elements.

The preparation of textbooks used in Islamic schools under the supervision of the Ministry of Religious Affairs should be the responsibility of the Ministry of Religious Affairs. However, what happens today is the textbook compiled commercially and equated between the Ministry of Education and Culture and the Ministry of Religious Affairs. It bring the effects of textbooks possible that are used are more general and less reflective of Islamic values.

\section{THEORY}

\subsection{Islamic Culture}

Syihabudin and Aam Abdussalam have conducted research on Islamic education related to the concept and its implementation in a golbal context (Syiahubdin \& Aam Abdussalam, 2015: 23-24). The finding of the research is to steer definitively to educators about the importance of contenc al-akhlaq al-karimah, teacher as a role model and revitalization of ijtihad in class. Based on these findings, it can be said that teachers will be role models for their studentsmto get good values. For that, teachers should have Islamic cultures reflected through attitudes and behaviors. How important it is to undesrtand and prcatice Islamic cultures in life considering Islamic cultures many noble elements in life.

Culture can basically be a guide for the survival of human life. Culture is also a form or sign that human life is still going on. In many aspects, the system of human knowledge is a cultural expression that is reflected through various expressions (Kusnaka Adimihardja, 2008: 4). Likewise eith Islamic culture which is the stories and reading materials that can be used as a source of reference to a better life. The form of Islamic culture that should be seen one of them can be taken from the letter of Ar-Rahman. This letter a very deeply meaning and functions in all context of life. In this letter men are commanded to uphold justice and do not reduce justice, but in many ways humans keep violating it. Violation of the letter resulted in the emergence of the nation's problems (Ary Ginanjar, 2008: 15).

Based on the above explanation it can be said that the Islamic culture that should be reflected in the textbook covers many things. These should be exemplary either directly or inderectly. The forms that can be describe one of them must be sourced from verses of Quran.

\subsection{Textbooks}

Henry Guntur Tarigan and Djago Tarigan giving several definition related with textbooks taken from the opinion of some experts. Textbook are book designed for classroom use to be carefully prepared by experts in field and equipped with appropriate and harmonized teaching means (Bacon) (Henry Guntur Tarigan dan Djado, 2009: 12). The material in the textbooks is the realization of the material listed in the currikulum.

For the simply put, H.G. Tarigan dan Djago Tarigan summarize some matters relating to textbooks.

a. Textbooks are textbooks intended for students at a certain level of education.

b. Textbooks related with specific field of the study.

c. Textbooks are the standard book, it is mean formal, reference, qualified, and there is usually authorization frim the competent authority.

d. Textbooks are usually compiled and written by experts in their respective fields.

e. Textbooks are written for certain instructional purpuses.

f. Textbooks are usually equipped with teaching tools.

g. Textbooks are written for a certain lecel of education.

h. Textbooks are written for support a teaching program (Henry Guntur Tarigan dan Djado, 2009: 13).

Nasution in Prastowo (2012) mentions the function of textbooks lessons.

- As references material by learners;

- As an evaluation material;

- As a helping tools to implementation cucrriculum;

- As one of the determinants of teaching methods or techniques that edicators will use;

- As a means to improve career and position (Prastowo, 2012: 169). 
Based on the above description can be said that many aspects that must be considered when preparing textbooks. The important aspect to keep in mind is that textbooks should be developed by experts in the field of study. In addition, teaching elementscan building positive culture and character values must also be considered.

\section{DISCUSSION}

In the discussion will be presented in two sub section, namely the presentation of the overall data and data analysis. The data presentation sub section will be presented in tabular form to facilitate the sorting and reading of data. Meanwhile, in the data analysis sub section will be presented with narrative model. The textbook used as a data source is an Indonesian Language book entitled "Berbahasa dan Bersastra Indonesia" for SMP/MTs, published by the Book Center of the Ministry of National Education. This book was chosen with the consideration that this book is also used in Islamic schools, namely Madrasah Tsanawiyah which is should have its own book as a distinction of Islamic values.

\subsection{Presentation of Data}

\begin{tabular}{|c|c|c|c|c|}
\hline No & $\begin{array}{l}\text { Islamic } \\
\text { cultures }\end{array}$ & $\begin{array}{l}\text { Representasti } \\
\text { on }\end{array}$ & Clear & $\begin{array}{l}\text { Not } \\
\text { Clear }\end{array}$ \\
\hline \multirow[t]{2}{*}{1} & Akhlakul & Honest & & $\mathrm{V}$ \\
\hline & $\begin{array}{l}\text { Karimah with } \\
\text { others }\end{array}$ & $\begin{array}{l}\text { Dicipline } \\
\text { Help }\end{array}$ & V & $\mathrm{V}$ \\
\hline \multirow[t]{2}{*}{2} & $\begin{array}{l}\text { Akhlakul } \\
\text { Karimah with }\end{array}$ & $\begin{array}{l}\text { Keeping } \\
\text { Nature }\end{array}$ & & V \\
\hline & $\begin{array}{l}\text { environment/na } \\
\text { ture }\end{array}$ & $\begin{array}{l}\text { Keeping } \\
\text { enviorment }\end{array}$ & & V \\
\hline
\end{tabular}

\subsection{Data Analysis}

Akhlakul Karimah is important to be owned not only by students and teachers, but by everyone. It is based on the verse that Islam is the religion rahmatan lil alamin, mercy for the whole of nature. That is why, all Muslims should be a people who can be a blessing for all other people. Therefore, the dakwah associated with this morality is not merely delivered directly and orally but can also through the means of learning. This means that is important to remember that textbooks are one of the learning tools that are carried and read by students. Textbooks almost daily are used as reference learning by both teachers and students.
For that, the habit of reading good things is expected to have an impact on good morality as well. In the textbook that became the source of this data is still found a lot of text or images that are less appropriate or less to teach akhlakul Karimah to others.

a. Honest

Being honest becomes an important sharacter to be owned by students and teachers. Various activities undertaken in school require that all parties in the school must have this trait. With this embedded nature from school it can be brought until the students grow up and enterinto real social life. The Indonesian nation is at an alarming stage for this honest nature. This can be seen from increasing percentage of corruption. More narrowly, it can be seen that many teachers and students are known to perform inappropriate acts when conducting the exam. Teachers and students are known to be equally dishonest in dealing with exam questions. Clearly the exam activities are conducted in a closed and ot allowed to tell answers to other parties. However, it is deliberately ignored.

This is one of the causes is the nature of honest not implanted early through the learning process. One that is visible is in textbooks. There is no command either directly or implicitly requiring the students to be honest. This has an impact on student learning activities that also take place with dishonest. The text of the command in the textbook used is direct command and mentions directly about honsety. Although not all of these, but in geneal are found to be such. Like the following data.

1) Lesson 1: Events

"Selamat berjumpa di tahun ajaran baru ini. Semoga di kelas yang baru, kalian dapat mengawali proses belajar dengan semangat yang baru".

"Dengan tekun dan teliti, kalian pasti dapat menunjukkan kemampuan kalian”.

In the text above, learning begins with greeting students. In it only convey the normative things that the beginning of the new school year should be the siprit. It should, at the earliest opportunity become an important time and point to convey a message of honesty. Even if it is considered as an early greeting, maybe the message of honesty can be accomplished in the second text, which is about the nature that must be owned to show the ability possessed. 
Attitudes are emphasized more on the formal ability or wordly ability, ie diligent and meticulos. Although the ability is important but it will be more imposing if the students are also ordered to have honest nature.

2) Lesson 2: Activity

"Mari, kita mulai pelajaran ini dengan motivasi untuk selalu berprestasi”

The text above also describes a message that is normative and formal impressed. In it all elements must have the motivation to perform, and the achievment itself is actually the result. Going to school or doing learning activities is essentially doing a process. Many processes must be passed before the students finally have the achievement. Therefore, in the textbook should also be conveyed about the process that must be passed, one of which is the spirit to always be honest so when it comes to achievement is something that is should be. As many motivators have pointed out, what is the point of getting a lot of things but if they are obtained through dishonesty. For that, in achieving the expected achievement in a textbook will be better delivered also ways to acvieve these achievements. One of them is to invite to always have honest nature.

3) Lesson 3: Tourism

One of the material in Lesson 3 is to make a letter of service. This material is intended to equip students if later they plunge into the world of work that requires them to make letters. Many elements must be met when creating and composing a letter. One of elements that must be met is the completeness of the information submitted. The completeness of this information requires the creator to convey everything honestly. Likewise in this material, implicitly invites students to be honest when conveying information in the letters they make. Like the command in the following text.

"Selain penggunaan bahasa baku dan beberapa hal di atas, yang harus kaliah perhatikan dalam pembuatan surat dinas yaitu kejelasan isi atau maksud dan keterangan lainnya. Dalam hal ini, maksud dari surat yang kalian buat dapat berisi atau berupa undangan, panggilan, jawaban, penawaran kerja sama, atau hal lainnya. Berkaitan dengan keterangan atau hal-hal yang menyangkut penjelasan dari isi ditulis secara lengkap."

The text above implicitly asks the student to inform everything completely. Here is expected that students can be honest when delivering all information, whether relatedto the identity or activities to be held. The text above when give meaning directly there is no message to be honest. However, if examined more deeply contains a message that when conveying $\mathrm{n}$ information should convey what it is and honest.

b. Discipline

The texts that contain the message or the values of discipline are mostly found in imperative forms. Like the "do this task a well", "do the following correctly", "discuss with your friends", and some other commands. The form of imperative text do not directly contain the values of discipline, but rather on the implied meaning. In the meantime, for the meaning is conveyed directly is not found. The Islamic values that should appear in textbook related to discipline is to instruct students to things on time. Just as Islam command its people to pray in time, fasting at a predetermined time, and giving charity according to the rules. With such suggestions, what should be reflected in the textbook is a disciplinary suggestion such as the order. For example, students are explicitly asked to collect assignments "work on time" or "collect on time", or "fill in the agrred rules". Nevertheless, existing suggestion are quite representative in terms of disciplinary values. However, it still needs to be deeper in giving suggestions so that disciplinary values can be better understood.

c. Help

1) Lesson 4: Culture

"Namun, bahasa yang berbeda-beda tersebut dapat menjadi satu kesatuan. Meski memiliki budaya bahasa yang berbeda-beda, antara kelompok sosial yang satu dengan yang lain dapat saling berkomunikasi",.

The text above does not directly reflects or contains Islamic values in the form of help. However, the nature of communication is to interact with others. At the time of interaction is expected human can do well. One good deed when interacting with 
others is to help each other. The concept of helping in Islam is in terms of kindness, as the Quran tells us that "let you help each other in kindess". It will be more tied to the value of Islamic if accompanied by a message that when doing tasks, question, and discussions are expcted to put forward ethics to help each other in goodness.

\section{CONCLUSION}

Based on the above discussion can be concluded that textbook that has been used has not been represented Islamic culture. Akhlakul Karimah which is a reflection of Islamic culture has not been seen and illustrated in the selected text as well as in the instruction and material narrative. Many factors are possible to couse it. One of them is a textbook that has been used by Islamic school still used on the textbook that compiled in general. It is very likely to be the couse becouse if it is generally compiled then the language or texts used/selected are generally accpetable languages and texts as well. Thus, the Ministry of Religious Affairs as the institution that oversees the religious school should have a policy to compile a separate textbook by referring to the curriculum in general.

\section{REFERENCES}

Andi Prastowo, Panduan Kreatif Membuat Bahan Ajar Inovatif, (Yogyakarta: Diva Press, 2012)

Ary Ginanjar Agustian, Sapa, (Jakarta: PT. ARGA Publishing, 2008)

Henry Guntur Tarigan dan Djado Tarigan, Telaah Buku Teks Bahasa Indonesia, (Bandung: Penerbit Angkasa, 2009)

I Gusti Putu Suharta, "Pengaruh Penstrukturan Buku Ajar dan Strategi Belajar terhadap Prestasi Belajar", http://www.jurnal.pdii.lipi.go.id/admin/jurnal/ 301974656.pdf 4 .

Kusnaka Adimihardja, Dinamika Budaya Lokal, (Bandung: C.V. Indra Prahasta dan Pusat Kajian LBPB, 2008)

Syiahubdin dan Aam Abdussalam, "Islamic Education: Its Concepts and Their Implementation in the Current Contxt", dalam Jurnal Tarbiya: Journal of Education in Muslim Society, 2 (1), 2015

Tarmizi Taher, "Menuju Ummatan Wasathan: Kerukunan Beragama di Indonesia”, (Jakarta: PPIM IAIN Jakarta, 1998) 